Covered in: ERIH PLUS, CEEOL, Index Copernicus, CrossRef, CrossCheck, J-Gate, Google Scholar, Ideas RePeC, Econpapers, Socionet, KVK, WorldCat.

\section{Arguments for a School Digital Mediation Guide for Romanian Counselor Teachers}

\section{Anda Anca RODIDEAL ${ }^{1}$}

${ }^{1}$ University of Bucharest, Faculty of Sociology and Social Work, anda.rodideal@drd.unibuc.ro
Abstract: Today, when the ubiquity of new interactive technology is undeniable and children and teenagers are between the highest internet consumers, gaining advantages but also being exposed to lots of risks, the educational institutions should open their gates and integrate it within their daily practices and curriculum. But, even the unprecedented pandemic situation forces its limits, requiring globally the online education to replace the traditional ones, the issues are far more complex, taking into consideration the risks children are facing online and the lack of support they are receiving. This paper focus is on the Romanian educational system, aiming to argue for fostering changes and to offer a sociological reasoned perspective on what can be done to give children and parents valuable information about minimizing the internet risks and highlighting its benefits. Recent researches results regarding children's digital behavior and parental digital mediation strategies emphasize the need for teachers' involvement to digitally mediate the relationship between children - technology - family and school. The radiography of the Romanian educational system's actual situation points to the digitalization gaps, but also the opportunities, the school counselor teachers being a key resource in this issue. Considering also the valuable insights offered by the good practice examples from different European countries, this paper shows the research results of piloting a guide developed for the school counselor teachers to equip them with the relevant information needed to face the emergent digital issues affecting children, teenagers, and entire family well-being.

Keywords: School digital mediation; digital competences; internet risks; internet opportunities.

How to cite: Rodideal, A.A. (2020). Arguments for a School Digital Mediation Guide for Romanian Counselor Teachers. Logos Universality Mentality Education Novelty: Social Sciences, 9(1), 84-100. doi: 10.18662/lumenss/9.1/35 


\section{Introduction}

The fact that children and especially teenagers are between the highest internet and digital technologies consumers is a certitude, proved by recent data: in 2019, 80\% of the children 12-16 years old in Europe used their smartphones to access several time per day the internet (Smahel et al., 2020), and $98 \%$ of those aged 16-19 years old (Eurostat, 2020). Parents, researchers, and policymakers are equally concerned about the risks they are exposed to due to these increased consumption habits, especially because they are doing it privately, mainly through their mobile phones, avoiding parental or other adults' supervision, being exposed to lots of risks. The EU Kids Online 2020 comparative survey report from 19 European countries points few important features regarding the children 9-16 years old internet usage patterns: they spent almost 3 hours/day on the internet (167 minutes' average, and 229 minutes/day those of 14-16 years old), mainly for communicating with friends, watching videos or listening to the music (more than $60 \%$ of them) but almost twice less for school work $(34 \%$ never or hardly ever). If something bothered them online, they preferred to address to peers $(50 \%)$, parents $(40 \%)$, or better do nothing $(19 \%)$, than to talk to a teacher (5\%) (Smahel et al., 2020). All these data prove that being online it was perceived by children and teenagers as an informal, private, entertaining activity, just the prolonged playing environment from their offline world, with the benefit of feeling free to act and react, to pursue their interests or communicate with whom may want.

This situation has been changed suddenly when during the COVID19 pandemic the schools were closed - 90\% schools from 184 countries on 1 st of April - and for 1,5 milliards students the educational systems were forced to find ways to continue the education through digital technologies, online (UNESCO, 2020).

In this period internet traffic has increased by $50 \%$ in the developed world, with schools and services moving online, which for children and adolescents has translated into even more Internet time, i.e. greater exposure to opportunities and also to risks (Fleming, 2020). UNICEF draws attention to the growing online risks for children during this disruptive period, in which even easier they can become victims of cyberbullying, sexting and other forms of online exploitation, conclusions based on the results of the FBI and Europol reports (Buechner, 2020). In these circumstances, UNICEF (2017) is reinforcing the position that all those involved - parents, teachers, and digital industry representatives - must adopt to keep children 
safe online: parents to ensure that children's technology has all the safety settings active, speaking openly with children about online hazards, establishing clear rules on the use of the internet and be aware of potential stress signs of children; teachers to inform themselves about new policies on online safety of learning technology-mediated, to promote and monitor positive online behavior and to ensure that children can access school counseling advice; technology companies to promote and ensure online safety and accessible means of digital education, to support and offer access conditions for those in disadvantaged environments (Buechner, 2020).

\section{Particularities of the Romanian situation}

In these conditions of uncertainty on how socio-professional life and education will continue offline and/or online due to the COVID19 pandemic, given the major importance that the internet and technology have acquired as the main solution for ensuring the continuation of activities under social isolation, in Romania, the emphasis is on developing children, teachers, and parents digital competences. All of them now are learning and deepening the use of various internet programs, software, and applications to benefit as most as possible of the opportunities that the online environment brings.

Before that, in Romania the digital consumption habits of children and teenagers were similar with their European peers, the cultural specificity adding more issues: daily mobile phones usage was high, $87 \%$ of $9-16$ years old children in 2019, mainly for informal-entertainment activities - for communication with friends and families" (77\%), ,buying things online, or just checking for the prices" $(41 \%$, ) spending time playing online games" $(60 \%$, ) (Smahel, 2020). The Romanian children were confident in their digital skills, being above the European average (8 points, compared with 7,8 average), even one-third of them said that something bothered them online in the past year. Main problems encountered online were: cyberbullying $40 \%$; exposure to harmful content, especially extreme violence and hate messages (42\%); data misused $(23 \%)$ - the values are the highest in Europe and twice bigger than the European average $(11 \%)$ at almost all the questions, from stolen personal data, to losing money online; excessive time spent online, the number of those who „have gone without eating or sleeping because of the internet" (11\%) being almost three times bigger than EU average (4\%), and almost 10\% experienced more than 3 from 5 criteria for excessive internet use, being between the highest in Europe; sexting $(25 \%)$; accessing sexual content and seeing sexual images (36\%), and only 
$17 \%$ were happy about it; meeting unknown people online $(38 \%$ of the $9-$ 16 years old children), and $23 \%$ of them meeting face-to-face with these people (Smahel et al., 2020). When encountering these risks, like their European peers, they prefer to talk with a friend (43\%) or with parents $(39 \%)$, but only $4 \%$ are talking with a teacher or another professional. Even worse, $45 \%$ of them declare they did nothing after the event occurred, only $7 \%$ reported the issue online, $8 \%$ changed the privacy settings and $18 \%$ blocked the person (Smahel et al., 2019), proving that Romanian children are not prepared to react properly if are facing internet risks.

A possible explanation and also the solution for minimizing the online risks could be enhancing mediation strategies used by parents and teachers, because, as the same report shows, in Romania, $46 \%$ children said that "never, or hardly ever" the parents talked to them about their internet consumption habits. Even the children were aware of the idea of using safely the internet, $84 \%$ of them saying that "they know about such things from parents, teachers or peers", the parental active mediation remains low, and also the restrictive ones - about 20\% reporting that their parents are controlling their internet usage, and only $15 \%$ of the younger ones were not allowed to use social networking sites. In harmony with these results, the inverse mediation - children helping parents with technology - is reported by almost $50 \%$ of children (Smahel et al., 2020), proving that parents were not so confident in their digital competences, preferring to consider that their children know what to do online and how to handle the risks.

Even this EU Kids Online (2020) report did not present a detailed situation regarding the mediation made by teachers in schools, other data offers a perspective on how the Romanian education system implement the strategy of building children digital competences and safeguarding them online, as the European Council recommend through the "Action Plan for Digital Education, 2018" (EU, 2018). The main steps in this direction have been taken in the last three years: the Information and Communication Technology (ICT) studies have been introduced from the 5th grade in the compulsory pre-university curriculum; all the manuals were digitized and made accessible online in a rich version (https://www.manuale.edu.ro/); targeted interventions related to online safety were available by school request, from NGOs like Save the Children Romania - through the "Net time" („Ora de net") program, or from Media wise - media education programs -, or the Romanian Police, through a specialized department. However, at the national level, standardized information on online risks and opportunities is minimal in the curriculum (partly developed in ICT and Guidance and counseling manuals). Also, there is no standardized teacher 
training program for the acquisition and further teaching of digital skills, as the logistics needed are lacking, not all the children having access to a computer and internet in schools. The main topic addressed in schools is the one related to bullying and cyberbullying, meaning that Romanian students are not receiving comprehensive information in these directions.

The unexpected situation, triggered by the COVID19 pandemic, with schools closed and the completion of the school year 2019-2020 moved online, brought to light the need to integrate technology into education and also the problem of underfunding education and the disparities it causes. By shifting the weight of the provision and access to online education to parents - Order 4135/21.04.2020 requires parents to ensure proper conditions for an online school for their children - one month after school closures, the education minister announced that ca. $40 \%$ of students can not participate in online lessons due to lack of equipment, establishing a relaxation of the grading and evaluation conditions for them.

Neither for the $63,7 \%$ pupils who learned from home by interacting with teachers through technology - according to the study conducted in April 2020 by the National Student Council through an online questionnaire with 11.958 students responding -, the situation was not easy, depending on the type of technology, the internet network, and the digital skills of both pupils and teachers. The subjects students reported as most learned online were Romanian (74\%), mathematics (62\%), first foreign language (49\%), history $(45 \%)$, and computing (41\%). There were used various applications and platforms, from direct-interactive ones - such as Zoom, Google meets or Skype - to the indirect- interactive ones, like Google classroom, Microsoft Teams, Digitaliada, or creating groups on social media platforms such as Facebook, or WhatsApp, depending on the teacher's and students' technical-digital skills and capabilities. These data are confirmed and enhanced by other studies realized with Romanian students, parents, and teachers during the same period. They revealed that only $63 \%$ of primary classes students have access to an exclusive device with an internet connection, compared with about $70 \%$ pupils from the gymnasium and high school. Also, $40 \%$ of the parents declared that they were spending three or more hours per day helping and sustaining the educational activities of their children (IRES, 2020). Representative office of UNICEF in Romania carried out another type of research, a "fast evaluation" (only with the local public representative actors at the community level, as the mayor, doctor, school director, teachers, priest, NGO representatives, or social workers) targeting the vulnerable families and children situation during the pandemic. The conclusions of the questionnaire (applied in rural and urban areas from eight 
Romanian counties) show that almost $80 \%$ of children from disadvantaged families did not have access to IT equipment and internet, and for about $60 \%$ of them, the main barriers to online learning were the lack of internet connected devices and digital competences of parents, teachers, and children alike. To overcome these issues and maintain the children's education, in some desperate cases teachers collaborate with the local mailman or other workers to deliver the educational materials to vulnerable children from Romanian villages (UNICEF, 2020).

Given the circumstances of the sudden shift to online education, it can be considered that a high percentage of teachers have adapted quickly, acquiring a set of digital skills. In 2018, only 4\% of the Didactic Center House (CCD) national training offer concerned ICT skills (Horga, 2018). The technology was not very often used for teaching and learning in the classroom: less than half of the pupils surveyed in national research conducted by Save the Children Romania in 2018 said they used technology in classes, including computer science, but $87 \%$ of them are using it during breaks, and 40\% secretly during classes (Gradinaru, 2019). EUKids Online 2018 survey shows that $30 \%$ of students report that teachers are directing them on how to use the internet safely and for exploring and learning new things (Velicu, Balea, \& Barbovschi, 2019).

It is also important to reflect on the differences between what the results of pre-pandemic research were expressing and the reality of postpandemic online education, on the discrepancy between what appeared to be a lack of teachers' digital skills, and what has been proven to be possible, from less than $10 \%$ teachers who participated in digital skills development courses to more than $60 \%$ teachers who used online learning platforms extrapolating the results presented before.

Concluding, the effects of the COVID19 pandemic on education in Romania, forcing the main educational actors to adapt to the online environment, led those who have access to technology to develop their digital skills and competences, leading the school to a new level. Also, there is hope to be continued this digitalization of education after returning to the classroom, when it will be known better how technology can be used to complement and potentiate face-to-face learning, without replacing it. In these circumstances, the need for actualized information and training for teachers regarding the opportunities and risks of the virtual world for children and adolescents, become as bigger as the time students spend online increase. 


\section{The need to develop a digital mediation guide}

Information on the risks and opportunities of the Internet for children and adolescents can be found in the Romanian online environment by those concerned, but it is disparate, newer, or older, more or less congruent and scientifically validated and this creates a certain degree of uncertainty for parents and teachers alike. In Romania, apart from various information provided by magazines, newspapers, or blogs, large telecommunications companies have included on their websites in the last year entries for warning parents about online risks. For example, Telekom offers details on "Child Safety on the Internet" and direct connection to the "happy Graf" application developed by the Children's Phone Association (https://www.telekom.ro/despre-noi/responsabilitate/piatatelecom/siguranta-copiilor-pe-internet/); Vodafone offers parental control applications via secure Net, an area of the site with many explanations about how parents can control children's access over the Internet (https://www.vodafone.ro/personal/asistenta/aplicatii-si-servicii/secure-

net/); Orange through the "for tomorrow" Social responsibility Platform, offers "digital education", both online safety tips and solutions, and opportunities to develop digital skills for children through online workshops (https://responsabilitate-sociala.orange.ro/educatie-digitala/); Kaspersky Romania makes available to parents free of charge "safe Kids", an application to control and monitor children's activity online. (https://www.kaspersky.ro/safe-kids).

Together with these initiatives, only two NGOs are very active in this area: Save the Children Romania with "sigur.info", a website that has been providing comprehensive information for children, parents, and teachers about online dangers and ways of protection since 2008, including also the possibility to complain about online safety abuses and issues (https://oradenet.salvaticopiii.ro); MediaWise, an NGO which provides educational resources for teachers to support classes of media and digital education on various topics, from cyberbullying to fake-news and the development of skills for critical analysis and thinking on the media (http://mediawise.ro/resurse/resurse-educationale/).

In the absence of a compulsory curriculum on these subjects, although access to all this information is free of charge and only at a click away, the extent to which teachers and/or parents choose to use educational resources is random, usually being used when problems arise, and less for preventive purposes. 
Considering school as an environment providing equal opportunities for development to all children, taking into account EU wide recommendations for digital literacy training and balanced use of technology to improve the well-being of the earliest age, I consider it obvious that a guide is needed in this direction, because in the current Romanian curriculum there is a lack of systematic and complete education concerning the opportunities and risks of the internet for children and adolescents.

Such initiatives existed before, in 2014 Save the Children Romania produced and published a "Guide for the safe use of the Internet", based on the research findings of the EU Kids Online Network 2010 - 2013, dedicated to teachers, containing detailed explanations and models of classroom activities regarding opportunities and, in particular, the risks of the internet (Roman, 2014). It was not re-edited or updated afterward, and the awareness campaigns that the organization carried on further, at the national level, it focused predominantly on bullying and cyberbullying. Another good practice model is a guide developed under a European COST program, in 2017, "Be a smart parent in the digital age", dedicated to parents with young children up to 8 years, which includes information and advice from European research on the EU Kids Online network (Hawkins \& Hyatt, 2017).

In the same idea, but using current information, based on international research results from the last 3-4 years and also empirical data from local research, I propose that a digital school mediation guide addressed to school counselor teachers should be developed. I have chosen the school counselor teachers category, as in the context of the social digital transformation, they could become "resource teachers" in the educational system, capable to support all actors involved - pupils, parents, and teachers - in adapting and doing everything for the best interests of children. School counseling is the kind of counseling addressed to educational actors - pupils, parents, and teachers - to maximize the positive educational effects of the school on children. It is offered to everyone, especially for those who at some point in life have difficulties, its main aim being to make the educational intervention more efficient and to minimize conflicts that have a disruptive effect on learning. It implies also the training of pupils' psychosocio-occupational skills and their educational and professional carrier orientation in line with their abilities, attitudes, and skills, attempting to relate the aim of the educational activities to the demands of the labor market and global society. The intervention of the school counselor teacher involves both individual counseling meetings with pupils, parents, or teachers, as well as with classes of pupils, groups of parents, or teachers. 
They have the abilities and openness to become the resource teachers regarding digital mediation in schools, and that is why they need to be exhaustively informed about the opportunities and risks of the internet for children, to prevent and positively influence the relationship of all those involved with technology, and promote its adaptation and integration in school (Tomsa, 2001).

To cover their information needs on how children and adolescents relate to technology, I propose to be developed a comprehensive material on this topic, called "Digital School Mediation Guide", that will fully incorporate the information needed by a teacher to deeply understand how the internet influences and affects the lives of students and their families. This will enable teachers to use different digital mediation strategies within the school, in line with their students' characteristics, to leverage opportunities, and minimize the risks of the internet. This guide is not intended to be a collection of methods of integrating technology into teaching, but an exhaustive information material, the basis for the work of school counselors teachers, who in all their relations with pupils, parents, and teachers must take into account how access and use of technology influence them.

In this regard, I believe that the Digital School Mediation Guide should include:

- information on the specific digital behavior of children and adolescents in Romania, according to the latest research in the field, as teachers must know what to expect from children;

- details of the internet opportunities for them, as the empirical research has shown, because teachers tend to have a negative perception of the effects of the internet on children, and are most prone to child-related harm; it is important to enforce the positive usage of digital devices, in more creative ways, for self-developing and weel-being;

- complex information on the risks of the internet for children, much more than bullying and cyberbullying, because other risks are also present in the online life of Romanian children;

- detailed information regarding parental digital mediation strategies, as they influence the most the online and offline behavior of children;

- other relevant information, useful educational resources as a starting point for integrating these subjects into training activities within school activities.

Before starting the construction of the guide, I considered appropriate to conduct a pilot study, to verify if this information is considered relevant also for the target group, or if there is more information 
they need and should be added. Given the constraints of the moment, this study was conducted using an online questionnaire, which was sent exclusively to school counselor teachers at the end of April 2020, through online WhatsApp closed counselors groups in Bucharest and on the dedicated Facebook school counselor group, thus receiving answers from all over the country.

\section{Pilot research on the teachers needs of a Digital Mediation Guide}

The pilot research on the extent to which the content of the proposed Digital School Mediation Guide is considered relevant by school counselor teachers has been carried out online, through a questionnaire that was completed by 40 school counselors teachers between 24th of April and 10th of May 2020, either by accessing the link sent through the online networks of school counselors teachers groups from the Bucharest sectors, or on the dedicated Facebook group of the school counselor teachers from Romania.

The research aimed to verify to what extent the content proposed to be included in this Digital School Mediation Guide corresponds to the general needs and expectations of teachers in their work, and especially during the 19 COVID pandemic and the shift of education in the online environment.

Building on the main content elements proposed to be included in the Guide, the working hypothesis established for this pilot research were:

1. School counselor teachers are aware of their important role in the digital mediation of children and families and are pro-actively seeking information in this direction.

2. School counselor teachers are equally interested in all the opportunities and risks of the internet for children and adolescents.

3. School counselor teachers are equally interested in all digital parental mediation strategies.

4. School counselor teachers fully understand the usefulness of technology in education, they used it and intend to continue to use it, and are very interested to learn new applications and methods to potentiate online communication.

The questionnaire applied included 21 questions, starting with a question related to the understanding of the confidentiality conditions and consent given by participation, 13 closed and open questions, and 7 demographic-identification questions. Among the 40 respondents is just 1 man - which is in line with the female majority distribution in the Romanian 
school counselor teachers group. Half of the respondents are from Bucharest, the others from various counties in the country, 90\% are between 36 and 55 years old, only 1 person is under 35 years old and 3 persons over 56 years old. The vast majority are experienced teachers, more than $80 \%$ of them have first and second educational grades, only 2 teachers are first-time teachers. The majority of them are secondary school teachers - 25 persons, followed by high school teachers 18 persons, primary and pre-school teachers respectively 12 and 13 persons. It is worth mentioning that in Romania the minimum standard is one school counselor teacher for at least 800 pupils, school counselors often work simultaneously in several units, combined according to the spatial proximity, not to the children level, and can be simultaneously counselor on high school and kindergarten, or gymnasium and high school, or any other combination.

Although the main limitation of this research is the lack of representativeness due to the low number of responses - $10 \%$ of the Bucharest school counselors network and less than $10 \%$ of the country total - given the characteristics of respondents and the high degree of homogeneity of views in this professional segment, their answers are considered valuable for this pilot study and are reliable for designing this guide.

\section{Results}

As regards the results that we will interpret only as frequencies, because for this micro-study we do not need complex data, they proved to be helpful in better understanding how school counselor teachers perceive children's relationship with technology and how they understand to help them in this direction. Thus, following the working hypotheses, will be detailed the results, finding that they will not be always confirmed, and the inertia and resistance of the educational system to digital technological developments are still high.

First of all, the results show that school counselor teachers are not particularly interested in how the internet is used by children and adolescents: a person "does not know" whether is interested about and more than half of the respondents only rarely or occasionally inform themselves about it, if they receive information on the subject. Even the almost half of them are often interested - „often every month", or „,every week" (20\%), the first hypothesis is not confirmed, and it is not possible to consider school counselor teachers as more interested in this issue. 
As regards the topics of interest for teachers to be informed about children's general digital behavior, we find that they are all interesting for most of them, but very high values (over 30 responses) have only the items about the opportunities and risks of the internet in general, cyberbullying, cyberhate and addiction to online games \& the use of social networks. Unexpected were the few responses that consider useless, or not so useful, all the topics, mostly the research results information about children's general online behavior. Although more than half of the respondents said they are interested in all the subjects, in particular, less interest is seen in "developing children digital skills", the "ways children are using technology" - music, games, etc. - and "relate to their family", the issues related to the "misuse of personal data" and "technical problems", probably because of the inclination of this target group toward psycho-socio-educational problems. The opened question on the same subject mentioned the need for information on the negative effects on the physical health of children and the need for concrete examples on how this information can be presented to children or parents. In conclusion, the second working hypothesis is not confirmed, as teachers have shown an increased interest only in the risks of the internet for children, rather than for a deeper understanding of how the way they use technology affects their well-being.

Regarding the parental digital mediation, it should be noted that the notion ,digital mediation" was explained in the body of the question, but the closed items contained the "technical words" like ,active, restrictive, passive, inverse mediation", deliberately without details, because it was considered that the school counselor teachers should be familiarized with such classification and could be able to understand their meaning. About half of respondents considered all the information about parental digital mediation to be very useful, whether active, restrictive, passive, reverse, or emerging, with the least interest being in passive digital mediation strategies -12 responses consider it to be not interesting. As regards the answers to the same open question, there are few answers, showing there is an interest in the practical side, case studies, or the presentation of NGOs providing advice in this area. In conclusion, the third hypothesis is confirmed, since, as regards the distribution of responses among the five types of parental digital mediation exposed, approx. $70 \%$ of respondents think all of them useful and very useful, to be included in the guide.

Teachers' views about the use of technology in education were questioned through a series of questions, regarding their particular and general situation. First of all, they are more interested in the future, and less about the digital mediation strategies used so far in school, and more to find 
out the options and opportunities for bringing technology into school and pupils' perceptions about it. Teachers recognized that they have so far used less technology, with answers almost equally divided between "sometimes", "somewhat true" and "totally true I used technology in my classes", as compared to the pandemic period, where the majority answered that they are using technology-mediated communication - double that of those who have replied they already use it. In similar percentages, they say they will continue to use it in the future, and during class hours, too, considering that the hours where digital technology is involved are more attractive to students. On the other hand, asked what kind of applications they think are useful in the classroom, in the first position are the educational movies, followed by power-point presentations, various quiz applications, or the creation of audio-visual materials. Interacting through etwinning platforms is less appreciated, and social media is needed only for keeping in touch with students or their parents. The open responses demonstrated that some of the school counselor teachers have adapted and already use various interactive platforms and applications during the pandemic period, such as Zoom, Google Classroom, Kahoot, according to the needs of the school.

To deepen the extent to which teachers consider technology useful in the education process, another two open questions were asking what subjects they consider to be more or less useful/appropriate to use technology. Responses vary a lot, only 11 teachers considering that in any classes they can be used, while others considering either the sciences (11 responses) or the humanities subjects (13 responses), that can benefit from technology, and the subjects dedicated to developing skills - such as physical education, or artistical - as the most inappropriate to use internet applications (7 responses). In conclusion, the fourth working assumption is partially checked, in the idea that on the one hand school counselor teachers consider the technology useful in the educational process, have used it, use it and intend to do so, and that it can be useful in education, in the subjects they teach, including mentoring for pupils. But, on the other hand, their responses also show that they are still uncertain about technology and prefer the use of non-interactive, traditional media - applications, especially educational movies and power-point presentations, the less interactive ones, and do not imagine how the vocational-applicative subjects can benefit from the internet and online teaching. 


\section{Discussions and limits}

This pilot study regarding the need for centralized information for the educational staff to enhance the mediation strategies used by schools for promoting a healthy usage of the internet by children and families proved to be fruitful in offering more information as expected. The answers given by the counselor teachers prove that this domain of risks and opportunities of internet usage by children and teenagers is not so familiar for them, the generational gap is high within the Romanian educational system, so the need for a guide like this is a reality.

Even this study lacks the representativeness, being so small, and the sample size could not be controlled, being applied online, the usage of the close Facebook group of school counselors for applying offered consistency to the results, due to the homogeneity of this group. Also, being users of online tools, this group could be considered as having at least medium digital competences, meaning they are opened to and interested in this subject, so their answers are valuable because they already have a reasonable grade of understanding about these issues. Their answers prove the need for further research regarding the teachers' perceptions about integrating digital technology within education, and also to make them more conscientious about their major role in mediating technology used by the families, as a whole, with positive effects on children well-being. Teachers and parents should be partners in digital mediation of the technology used by children, to have a positive impact and raise the internet opportunities. This type of studies should be continued and expanded, because the proposal of a guide for school counselor teachers should be followed by a guide for all the teachers, because only through collaboration and integrated actions the school could become a referential point for children and parents regarding digital education and mediation. The lack of using the digital technologies within classrooms that was abruptly transformed by the pandemic situation, means that a huge gap within the Romanian educational system was suddenly fulfilled, even not perfect, but in a way that could give us hope that the opportunities of technologies for learning and teaching will be adopted and the risks minimized.

\section{Conclusions on the content of the Digital School Mediation Guide}

The need for a digital mediation guide in school emerged, given the previous and current situation resulting from the COVID19 pandemic situation, in conjunction with the results of the studies carried out before and the pilot study about the school counselor teachers' subjects of interest 
to be included in this guide. Taking into account the lack of consistent information within the Romanian school curriculum on how children and adolescents relate to the technology, the opportunities and risks they are exposed to, and the effective ways of integrating it into the educational process, the need for such a guide appears to be a necessity.

Taking into account the results of the research carried out, about how children and families use and relate to technology and the experiences generated by closing schools and moving to learn online, the main topics proposed to be introduced in this Digital School Mediation Guide are:

- An information chapter on how children and families use the internet in Romania, according to recent data research in the field, to familiarize teachers with their online behaviors and interests.

- A chapter explaining the types of opportunities and the types of risks children and adolescents encounter in the virtual environment, defining and detailing each of them. The opportunities explanations will be focused on communication and networking, information and education, personal development, digital and creative skills, and competencies needed to access the labor market. As for risks, all of them will be explained, both physiological ones affecting children's physical health and also the psychoemotional effects, with negative effects on the quality of personal and family life. Particular attention will be paid to the cases of students with special learning disorders and educational requirements, as a category vulnerable to online risks.

- Another chapter will be devoted to the issues of family digital mediation, to explain the classification and consequences of the different digital mediation strategies used by parents to mediate children's relationship with technology.

- The final chapter will detail how schools and teachers can use technology within the educational environment, i.e. to drive technologybased learning, based on successful models already implemented in other countries.

By receiving all these relevant and actualized information on the digital issue, through a deeper understanding of the implications and ramifications of integrating technology into the social life of all family members, school counselors teachers will be able to provide adequate support to students, teachers, and parents for enhancing the benefits and minimizing the risks of technology for them. The information presented in this guide will be based on actual scientific research data, selected from the scientific communications in Romania and abroad on the subject and will be presented in the form of a brochure that will be accessible online. 
Arguments for a School Digital Mediation Guide for Romanian Counselor ... Anda Anca RODIDEAL

\section{References}

Buechner, M. (2020). Keeping Kids Safe from Online Harm in Age of COVID-19.

UNICEF. https://www.unicefusa.org/mission/covid-19

European Union (EU). (2018). Communication From The Commission To The European Parliament, The Council, The European Economic And Social Committee And The Committee Of The Regions on the Digital Education Action Plan, COM/2018/022 final. https://eur-lex.europa.eu/legalcontent $/ \mathrm{EN} / \mathrm{TXT} /$ ? uri $=\mathrm{COM} \% 3 \mathrm{~A} 2018 \% 3 \mathrm{~A} 22 \% 3 \mathrm{AFIN}$

Eurostat. (2020). Digital economy and society.

https://ec.europa.eu/eurostat/web/digital-economy-andsociety/data/database

Fleming, S. (2020). Will the coronavirus break the internet? https://www.weforum.org/agenda/2020/03/will-coronavirus-break-theinternet/

Gradinaru, C. (2019). Studiu privind utilizarea internetului de către copii, Salvați Copiii România. https://www.salvaticopiii.ro/sci-ro/files/92/928fobffbffa-447a-9a27-df979ba1008f.pdf

Hawkins, N., \& Hyatt, T. (2017). DigilitEY: Smart-parenting-ROMANIAN, Fii părinte smart în epoca digitală. Un ghid cu sfaturi practice pentru părinții cu copii de până la 8 ani. https://library.parenthelp.eu/wpcontent/uploads/2017/05/DigilitEY-\%E2\%80\%94-Smart-parentingROMANIAN-v2.pdf

Horga, I. (Coord.). (2018). Raport privind nevoile de formare ale cadrelor didactice din învăț̆ământul primar și gimnazial în domeniul abilitării curriculare, în cadrul proiectului CRED. http://www.ise.ro/wpcontent/uploads/2020/04/A.3.1.Raport analiza de formare.pdf

Institutul Roman pentru Evaluare si Strategie (IRES). (2020). Școala în stare de urgență. Accesul copiilor școlari din România la educație online. Studiu național, mai 2020, Policy paper. https://ires.ro/articol/395/accesulcopiilor--colari-din-romania-la-educatie-online-----policy-paper

Kaspersky. (2020). Safe Kids. https://www.kaspersky.ro/safe-kids

Media wise. (2020). Resurse educationale. http://mediawise.ro/resurse/resurseeducationale/

Ministerul Educatiei Nationale. (2020). OMEC nr. 4135/21.04.2020 de aprobare a Instrucțiunii privind asigurarea continuității procesului de învățare la nivelul sistemului de învățământ preuniversitar.

http://www.isjilfov.ro/index.php?option $=$ com content\&view $=$ article\&id =3943:omec-4135-21-04-2020-de-aprobare-a-instructiunii-privindasigurarea-continuitatii-procesului-de-invatare-la-nivelul-sistemului-deinvatamant-preuniversitar\&catid=108:urgente\&Itemid=101 
National Student Council. (2020). Raportul privind accesul elevilor la educatie in mediul online. https://consiliulelevilor.ro/wpcontent/uploads/2020/04/Raport-privind-accesul-elevilor-laeduca $\%$ C $8 \% 9$ Bie- $\%$ C $3 \%$ AEn-mediul-online.pdf

Orange. (2020). Digital parenting. https://www.orange.ro/responsabilitatesociala/internetul-pentru-copii/index.html

Roman, G. (Coord.). (2014). Ghidul utilizării în siguranță a internetului. Un internet mai sigur pentru toți elevii. https://oradenet.salvaticopiii.ro/docs/Ghidul_utilizarii_in_siguranta_a_In ternetului.pdf

Save the Children Romania. (2020). Ora de net. https://oradenet.salvaticopiii.ro/

Smahel, D., Machackova, H., Mascheroni, G., Dedkova, L., Staksrud, E., Ólafsson, K., Livingstone, S., \& Hasebrink, U. (2020). EU Kids Online 2020: Survey results from 19 countries. EU Kids Online. Doi: 10.21953/1se.47fdeqj01ofo

Telekom. (2020). Protectia copiilor in utilizarea tehnologiei de comunicare. https://www.telekom.ro/despre-noi/responsabilitate/piatatelecom/siguranta-copiilor-pe-internet/

Tomsa, G. (2001). Consilierea si Orientarea in Scoala, București: Universitatea București. CREDIS.

UNESCO. (2020). Global Monitoring of School Closure. https://en.unesco.org/covid19/educationresponse

UNICEF. (2017). Children in a Digital World. https://www.unicef.org/publications/index 101992.html

UNIVEF. (2020). Evaluare rapidă a situației copiilor și familiilor, cu accent pe categoriile vulnerabile, în contextul epidemiei de covid-19 din România. Faza I, runda 3. https://www.unicef.org/romania/ro/documents/evaluare-rapid $\%$ C4\%83situa $\%$ C $5 \%$ A3iei-copiilor- $\%$ C $5 \%$ Fi-familiilor-cu-accent-pe-categoriilevulnerabile-0

Velicu, A., Balea, B., \& Barbovschi, M. (2019). Internet Access, Use, RisksandOpportunities for Romanian children - EUKIDS ONLINE 2018 project. http://rokidsonline.net/wp/wp-content/uploads/2019/01/EUKids-Online-RO-report-15012019 DL.pdf.

Vodafone. (2020). Copiii si internetul. https://www.vodafone.ro/desprenoi/implicare-sociala/responsabilitate-corporativa/copiii-siinternetul/index.htm 